\title{
GYALECTIDIUM AURELII (OSTROPALES: GOMPHILLACEAE), A NEW FOLIICOLOUS LICHEN FROM THE STATE OF MATO GROSSO, BRAZIL
}

\author{
Lidia Itati Ferraro ${ }^{1}$ \\ Robert Lücking ${ }^{2}$
}

Received: 26/09/2002. Accepted: 03/06/2003

\begin{abstract}
RESUMO - (Gyalectidium aurelii (Ostropales: Gomphillaceae), um novo líquen foliícola do Estado de Mato Grosso, Brasil). O líquen Gyalectidium aurelii é descrito como novo, tendo sido encontrado sobre folhas de Meliaceae na Chapada dos Guimarães, no Estado do Mato Grosso, Brasil. O novo táxon caracteriza-se por apresentar hifóforos marginais muito largos, com escamas projetando-se horizontalmente sobre o substrato. G. aurelii distingue-se de espécies semelhantes, como G. fantasticum e G. paolae, por seus hifóforos, os quais são incurvados (seguindo o contorno do talo) e têm a margem inteira, assim como pelo talo irregularmente verrucoso e não areolado. O gênero Gyalectidium contém agora 37 espécies.
\end{abstract}

Palavras-chave - espécie nova, Chapada dos Guimarães, Meliaceae

\begin{abstract}
Gyalectidium aurelii (Ostropales: Gomphillaceae), a new foliicolous lichen from the State of Mato Grosso, Brazil). The new species Gyalectidium aurelii is described from leaves of Meliaceae collected in Chapada dos Guimarães, in the State of Mato Grosso, Brazil. The new taxon is characterized by very broad, marginal hyphophores with scales that project horizontally from the leaf margin and are closely appressed to the substrate. G. aurelii is distinguished from similar species, such as G. fantasticum and G. paolae, by its hyphophores being incurved (following the thallus outline) and having an entire margin, and further by its irregularly verrucose rather than areolate thallus. The genus Gyalectidium now comprises 37 species.
\end{abstract}

Key words - new species, Chapada dos Guimaraes, Meliaceae

\footnotetext{
Instituto de Botánica del Nordeste (IBONE), Casilla del Correo 209, 3400 Corrientes, Argentina (itati_liq@ yahoo.com.ar)

2 Department of Botany, Field Museum, 1400 South Lake Shore Drive, Chicago, IL, 60605-2496, U.S.A. (rlucking@fieldmuseum.org)
} 


\section{Introduction}

The lichen genus Gyalectidium Müll. Arg. comprises mostly foliicolous species which are found in all tropical and subtropical rainforests throughout the world (Ferraro et al. 2001). Like other genera in the Gomphillaceae, Gyalectidium is characterized by hemiangiocarpous apothecia and non-amyloid hymenium, branched and anastomosing paraphyses, annelasceous asci, and conidiomata of the hyphophore type (Vezda 1979; Vezda \& Poelt 1987; Lücking 1997; Ferraro et al. 2001). Gyalectidium can be recognized at the genus level by its immersed-erumpent apothecia (Fig. 1A), with zeorine margin (both true excipulum and thalline margin present) and its squamiform hyphophores (Fig. 1B-F), with the conidial hyphae (diahyphae) being produces at the base of variously shaped scales. Most other genera in the family have setiform hyphophores which produce the diahyphae at their tips.

For a long time, the genus was believed to be poor in species, but detailed studies revealed an unexpected diversity, with 29 species accepted in a recent world monograph (Ferraro et al. 2001). Soon after the monograph was published, no less than eight further new species were discovered in collections of foliicolous lichens from Mexico and Chile (HerreraCampos \& Lücking 2002; 2003; in prep.; Lücking et al. 2003).

In this paper, we describe another new species of the genus, discovered in material collected by A. Schinini and G. \& M. Hatschbach in the State of Mato Grosso in Brazil, in 1997.

\section{Gyalectidium aurelii Ferraro \& Lücking sp. nov.}

Sicut Gyalectidio fantastico sed hyphophoris incurvatis minoribusque differt. - Type. BRASIL. Mato Grosso: Município Chapada dos Guimarães, surroundings of Chapada dos Guimarães, on leaves of Meliaceae, II to VIII/1997, A. Schinini, G. \& M. Hatschbach 33942 (CTES, holotype).
Thallus foliicolous, epiphyllous, crustose, forming small, rounded to very irregular, sometimes marginally dispersed patches $1-3(-5) \mathrm{mm}$ across and $10-20 \mu \mathrm{m}$ thick, with a cartilaginous, corticiform layer, irregularly to coarsely verrucose due to encrustation with calcium oxalate crystals (near the hyphophores with larger crystalline clusters), pale brownish or yellowish grey to pale greenish; verrucae $0.05-0.15 \mathrm{~mm}$ diam., whitish. Phycobiont a

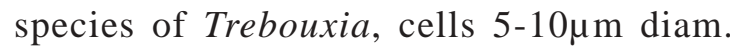
Apothecia not observed. Hyphophores frequent, formed at the thallus margin, projecting horizontally, very broadly squamiform and flabellate, usually recurved or irregularly bent (following the thallus outline), their margin entire, lacking appendages, $0.1-0.15 \mathrm{~mm}$ long $\times 0.4-1 \mathrm{~mm}$ wide, greyish brown but uppermost part pale. Diahyphae branched throughout, moniliform, segments sausage to drop-shaped, $5-7 \times 1.5-2 \mu \mathrm{m}$, colourless, with scattered algal cells $3-5 \mathrm{~mm}$ diam.

This new species is dedicated to Aurelio Schinini for his invaluable collections which add considerably to the knowledge of the lichen flora of northern Argentina and southern Brazil.

As stated in the introduction, the hyphophore scales in Gyalectidium are very variable and provide important characters to distinguish between species (Fig. 1B-F). While some taxa, such as the type species G. filicinum, have erect scales protruding from the thallus surface (Fig. 1B), in others the scales are adnate to the thallus (Fig. 1C) and often marginal (Fig. 1D-F). Mostly, the scales are unpigmented and whitish but might be darkened to pure black in a few taxa. Other specific characters are the presence of calcium oxalate crystals and their distribution in the thallus: they either form verrucae or large, sometimes completely confluent areoles.

Gyalectidium aurelii is characterized by adnate, marginal, dark hyphophore scales, in combination with a verrucose thallus (Fig. 1F). The species resembles two other species with broad, dark, marginal hyphophores with scales 
that project horizontally and are closely appressed to the substrate, viz. $G$. fantasticum Ferraro \& Lücking (Ferraro et al. 2001) and G. paolae Herrera-Campos
\& Lücking (Herrera-Campos \& Lücking 2002). However, these two species have an areolate rather than verrucose thallus (Fig. 1DE), and while the hyphophores of G. paolae
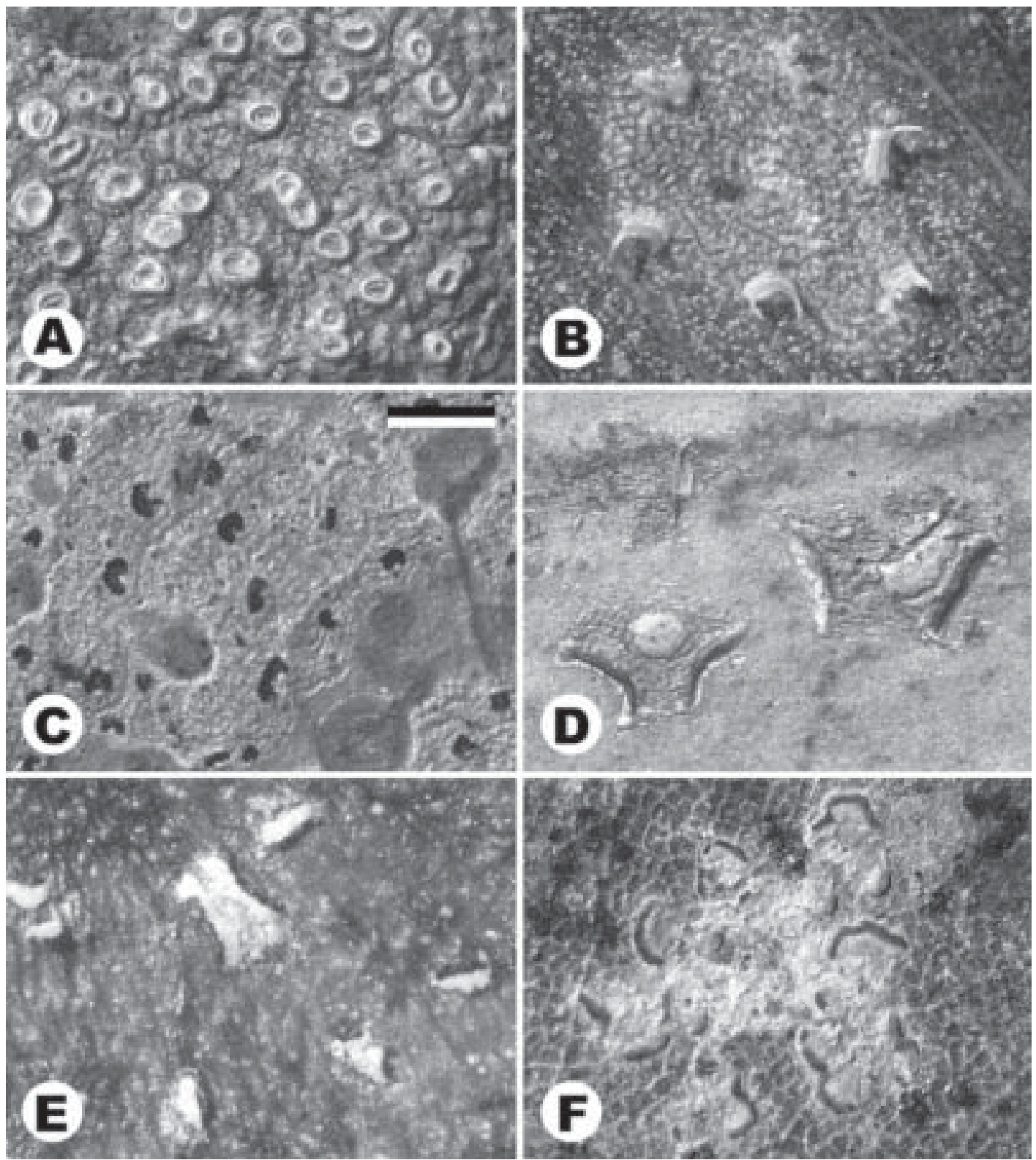

Figure 1. Thalli and hyphophores of Gyalectidium aurelii and related or similar species. A. G. filicinum (apothecia). B. G. filicinum (hyphophores). C. G. imperfectum (hyphophores); note the fine thallus verrucae. D. G. fantasticum (hyphophores); note the crystalline areoles. E. G. paolae (hyphophores); note the large crystalline bulges. F. G. aurelii (hyphophores). Scale $=1 \mathrm{~mm}$, in $\mathrm{D}=1.5 \mathrm{~mm}$, in $\mathrm{E}=0.5 \mathrm{~mm}$. 
are smaller and irregularly dissected, those of G. fantasticum are larger, usually recurved, and provided with two acute, lateral appendages. Another superficially similar species is G. imperfectum Vezda (Vezda 1994). It agrees with $G$. aurelii in the verrucose rather than areolate thallus (Fig. 1C), but its hyphophore scales are greatly reduced, leaving the diahyphal masses visible as dark, reniform spots on the thallus surface.

\section{Bibliographic references}

Ferraro, L. I.; Lücking, R. \& Sérusiaux, E. 2001. A world monograph of the lichen genus Gyalectidium (Gomphillaceae). Botanical Journal of the Linnean Society 137: 311-345.

Herrera-Campos, M. A. \& Lücking, R. 2002. The foliicolous lichen flora of Mexico. I. New species from Los Tuxtlas Tropical Biology Station, Veracruz. Lichenologist 34: 211-222.
Herrera-Campos, M. A. \& Lücking, R. 2003. The foliicolous lichen flora of Mexico. II. New species from the montane forest in Oaxaca and Puebla. The Bryologist 106: 1-8.

Lücking, R. 1997. Additions and corrections to the knowledge of the foliicolous lichen flora of Costa Rica, Central America. The family Gomphillaceae. Bibliotheca Lichenologica 65: 1-109.

Lücking, R.; Wirth, V.; Ferraro, L. I. \& Cáceres, M. E. S. 2003. Foliicolous lichens from Valdivian temperate rainforest of Chile and Argentina: evidence of an austral element, with the description of seven new taxa. Global Ecology and Biogeography 12: 21-36.

Vezda, A. 1979. Flechtensystematische Studien. XI. Beiträge zur Kenntnis der Familie Asterothyriaceae (Discolichenes). Folia Geobotanica et Phytotaxonomica 14: 43-94.

Vezda, A. 1994. Neue foliicole Flechten II. Nova Hedwigia 58: 123-143.

Vezda, A. \& Poelt, J. 1987. Flechtensystematische Studien. XII. Die Familie Gomphillaceae und ihre Glie-derung. Folia Geobotanica et Phytotaxonomica 22: 179-198. 